\title{
ТЕНДЕНЦИИ ИСПОЛЬЗОВАНИЯ ТИРЕ В СОВРЕМЕННОМ РУССКОМ ЯЗЫКЕ НА ПРИМЕРЕ ПУБЛИЦИСТИЧЕСКИХ ТЕКСТОВ)
}

\author{
Александра Чебан, Янина Крейчи

\section{TRENDS IN THE USE OF DASHES IN MODERN RUSSIAN (ON EXAMPLE OF JOURNALISTIC TEXTS)}

\author{
Alexandra Cheban, Janina Krejci
}

\begin{abstract}
Резюме: В статье представлены результаты исследования, проведенного на материале публицистических текстов наиболее популярных российских интернет-СМИ, целью которого являлось определение характера и частотности использования тире как пунктуационного знака. В статье также описаны современные тенденции факультативного употребления тире, не соответствующего общепринятым правилам пунктуации русского языка.
\end{abstract}

Ключевые слова: пунктуация, тире, тенденции использования тире, русский язык, публицистические тексты

Abstract: The article presents the results of a study conducted on the basis of journalistic texts of the most popular Russian Internet media, the purpose of which was to determine the nature and frequency of the use of dashes as punctuation marks. The article also describes modern trends in the optional use of dashes, which do not correspond to the generally accepted rules of punctuation of the Russian language.

Key words: Punctuation, dashes, trends in the use of dashes, Russian language, journalistic texts

DOI: $10.14712 / 9788076032088.5$

\section{1 Введение}

Пунктуация является неотъемлемой частью любого письменного языка. Согласно литературному словарю пунктуация представляет собой правила употребления дополнительных письменных знаков (знаков препинания), служащих для обозначения ритмики и мелодики фразы, иначе фразовой интонации. В современной русской пунктуации, наряду со строгой регламентированностью употребления знаков препинания, допускается их факультативное употребление. Это объясняется тем, что разные знаки могут использоваться для одной и той же цели, быть взаимозаменяемыми.

Лингвисты уже на протяжении многих лет изучают существующие тенденции факультативного употребления знаков препинания, выдвигают мнения и гипотезы касательно их появления и развития. Одним из первых зарождение факультативного употребления знаков препинания отметил Л. В. Щерба еще в начале прошлого столетия. Главы о факультативном употреблении пунктуационных знаков в свои справочники по русскому языку включал и Д. Э. Розенталь. В число современных лингвистов, изучающих данную проблематику, входят Н. С. Валгина, В. Н. Светлышева, А. Ю. Ларионова, Е. В. Брусницына, И. А. Долматова и другие. В данной статье представлены результаты исследования тенденций в области современной 
русской пунктуации. В статье описаны теоретические основы использования пунктуационных знаков; представлен краткий анализ публикаций, касающихся тенденций употребления пунктуационного знака тире; описана методология, ход и результаты исследования частотности употребления различных категорий тире, а также описаны тенденции факультативного употребления тире в публицистических статьях, опубликованных в наиболее популярных российских интернет-СМИ.

\section{2 Теоретические основы исследования}

\section{1 Регламентированная и нерегламентированная пунктуация}

В русском языке выделяются такие пунктуационные знаки, как точка, запятая, восклицательный знак, вопросительный знак, тире, многоточие, точка с запятой, дефис, скобки, кавычки. Согласно Н. С. Валгиной, Д. Э. Розенталю и М. И. Фоминой существует классификация деления знаков препинания на две категории: знаки препинания в русском языке делятся на отделяющие, благодаря которым возможно отделение частей текста друг от друга, и выделяющие, с помощью которых возможно выделение конкретных частей текста (Валгина, Розенталь, Фомина, онлайн). В категорию отделяющих знаков входят точка, вопросительный и восклицательный знаки, точка с запятой, двоеточие и многоточие. Скобки и кавычки входят в группу выделяющих знаков. Согласно Н. С. Валгиной запятая и тире при единичном употреблении выступают в роли отделяющих знаков, а при парном включаются в группу выделяющих знаков (Валгина [2], онлайн).

Помимо пунктуации, которая регламентируется «Правилами русской орфографии и пунктуации» (Лопатин, 2007), в современном русском языке также существует пунктуация нерегламентированная, которая от этих правил отклоняется. Такая пунктуация является ситуативной и всегда приспосабливается под конкретные функции определенных текстов. Н. С. Валгина и В. Н. Светлышева отмечают, что подобные ситуативные знаки «обеспечивают особую информативность и экспрессивность речи. Ситуативные нормы диктуются характером текстовой информации: знаки препинания, подчиненные такой норме, выполняют функции логико-смысловую (проявляется в разных текстах, но особенно в научных и официальноделовых), акцентно-выделительную (преимущественно в текстах официальных, частично в публицистических и художественных), экспрессивно-эмоциональную (в текстах художественных и публицистических), сигнальную (в тестах рекламных)», подчеркивая, что «такие знаки регламентированы характером этих текстов и существуют наряду $c$ общепринятыми» (Валгина, Светлышева, онлайн).

В русском языке также существует понятие факультативности знаков препинания. Данное определение характеризуется тем, что в настоящее время различные знаки препинания обладают схожими, т.е. синонимичными функциями. В современном русском языке выделяется 3 категории факультативных знаков:

- Знак собственно факультативный - по схеме «знак - нуль знака» (ставить или не ставить).

- Знак альтернативный - по схеме «или - или» (взаимоисключение знаков).

- Знак вариативный - по схеме «знак на выбор» (параллельное употребление знаков) (Розенталь, онлайн).

Общая тенденция употребления пунктуационных знаков, не отвечающего установленным правилам, отмечается Н. С. Валгиной: „наблюдения над практикой применения пунктуационных знаков в современной печати, особенно периодической, где новые веяния 
быстрее всего дают о себе знать, показывают, что ныне действующие правила несколько уже устарели и нуждаются в уточнении" (Валгина [2], онлайн)

Тенденции употребления пунктуационных знаков, отходящих от установленных норм, объясняются тем, что любой активный и живой язык, в том числе и русский, постоянно изменяется и развивается, а вместе с ним должна развиваться и одна из его частей - пунктуация. Н. С. Валгина пишет, что «поскольку пунктуация обслуживает постоянно изменяющийся и развивающийся язык, она также изменчива с точки зрения исторической. Именно поэтому в каждый период могут происходить изменения в функциях знаков препинания, в условиях их применения. <...> Изменения в функционировании знаков происходят постоянно, они отражают жизнь языка, в частности его синтаксической структуры и стилистической системы». (Валгина [3], онлайн). О развитии и изменяемости пунктуации говорит и М. В. Дивакова. Она пишет, что пунктуация как графическая система, функционирующая в современном русском языке, складывалась в истории русского языка, изменяясь графически, функционально и качественно, добавляя, что эти изменения происходили и происходят постоянно, что они отражают жизнь языка (Дивакова, онлайн). М. В. Дивакова высказывает мнение, что правила, стабильные и узаконенные специальными документами, всегда неизбежно отстают от своего времени, так как фиксируют определенный временной отрезок, а практика употребления знаков препинания всегда зависит от причин языкового и внеязыкового характера (Дивакова, онлайн).

\section{2 Регламентированное употребление тире как пунктуационного знака}

Тире - многофункциональный знак в русском языке. В предложении оно выполняет структурные, смысловые и экспрессивные функции. Н. С. Валгина, рассматривая функции тире, пишет, что «диапазон употребления тире действительно широк: во-первых, это фиксатор всевозможных «грамматических» пропусков, тире заполняет эти словесно пустые места; во-вторых, при отсутствии специальных лексико-грамматических средств выражения (при бессоюзии) тире способствует передаче на письме особых смысловых отношений - условно-временных и следственных, в устной речи эти значения передаются интонационными средствами; в-третьих, служит цели создания эмоциональноэкспрессивных качеств речи» (Валгина [2], онлайн).

На основе классификаций Д. Э. Розенталя и В. В. Лопатина можно выделить классификационную систему, регламентирующую употребление тире:

1) Тире в зависимости от структуры предложения

а. Тире в основной структуре предложения

- Тире между подлежащим и сказуемым

- Тире в предложениях с однородными членами

- Тире в предложениях с обособленными членами

- Тире в предложениях с уточняющими, пояснительными и присоединительными членами

- Тире при словах, грамматически не связанных с членами предложения

b. Тире в сложном предложении

- Тире в сложносочиненном предложении

- Тире в сложноподчиненном предложении

- Тире в бессоюзном сложном предложении

с. Тире в неполном предложении 
2) Тире соединительное

3) Тире интонационное

4) Тире при прямой речи

В отличие от установленных лингвистических правил русского языка в современных печатных изданиях часто встречаются случаи использования тире вместо двоеточия, запятой, скобок, кавычек, вопросительного знака, многоточия и т. д. А. Ю. Ларионова пишет, что «тире расширяет границы использования и часто заменяет другие знаки вопреки существующим правилам и в соответствии с авторским замыслом. Например, 1) тире используется вместо двоеточия <...> 2) тире используется вместо запятой в сложноподчиненных предложениях $<. .>$ Кроме того, тире ставится, чтобы избежать повторного использования двоеточия в рамках одного предложения» (Ларионова, онлайн).

\section{3 Краткий анализ результатов исследований употребления тире в текстах СМИ}

В настоящее время СМИ оказывают значительное влияние на культуру человека на интеллектуальном и поведенческом уровнях. А. Ю. Ларионова пишет, что «СМИ более чем за полвека превратились в источник языковых норм, потеснив русскую литературу. С позиции активных процессов ученые признают за СМИ ведущую роль в развитии современного русского языка» (Ларионова, онлайн). Читатели воспринимают информацию, в том числе и постановку пунктуационных знаков, как что-то пунктуационно, синтаксически или стилистически соответствующее нормам русского языка. Однако в некоторых случаях для привлечения внимания, для выделения тем, акцент на которых автор той или иной статьи хочет сделать, печатные издания отступают от регламентированных норм русского языка. И. А. Долматова пишет, что «желание рекламодателей экспрессивно выделить какие-либо конструкции приводит к тому, что в сознании обывателя это становится нормой (поскольку авторитет печатного текста небывало высок: написано, напечатано --значит, так оно и есть; значит, правильно)", добавляя, что «и обыватель сам начинает так же писать, ставя тире, где не надо» (Долматова, онлайн).

Согласно И.А. Долматовой для текстов современных СМИ характерны следующие случаи замены некоторых пунктуационных знаков знаком тире:

1) Тире вместо двоеточия

И. А. Долматова пишет о том, что наиболее ярко процесс замещения двоеточия знаком тире проявился в бессоюзных сложных предложениях (Долматова, онлайн). Подобное мнение высказывает и Н. С. Валгина, говоря, "что в настоящее время выявляется тенденция к вытеснению в ряде случаев двоеточия знаком тире. Употребление двоеточия сводится к очень конкретным и явно немногочисленным случаям, оно закрепляется в позиции перед перечислением. В других же случаях, даже когда это поддерживается ныне действующими правилами пунктуации, двоеточие практически заменяется тире» (Валгина, онлайн).

Тенденция употребления тире вместо двоеточия наглядно представлена в примерах ниже:

- «Лучше шишки собирать зимой - в это время в них наверняка окажутся семена» («Наука и жизнь»). В данном примере вторая часть предложения является причиной/обоснованием первой части. Согласно «Правилам русской орфографии и пунктуации» в данной ситуации должно использоваться двоеточие (п.2, глава 129, раздел «Пунктуация»). Однако, согласно примечанию 2 той же главы (Долматова, онлайн), постановка тире в данном случае также допустима. 
- Людей большей частью интересовала не политика, а социальные проблемыплохие дороги, связь, отсутствие тепла в домах и другие беды» («Комсомольская правда»). В данном примере обобщающее слово стоит перед перечислением однородных членов. Согласно «Правилам русской орфографии и пунктуации» в данном случае должен использоваться знак двоеточие (глава 33, раздел «Пунктуация»). Однако, согласно примечанию, допустимо используемое в современной практике печати при всех позициях обобщающих слов употребление тире, в том числе - перед перечислением (Лопатин 2007).

Данные примеры отражают тенденцию замещения знака двоеточие знаком тире, хоть это и не выходит за пределы существующих норм, так как это оговорено в примечаниях «Правил русской орфографии и пунктуации", что подтверждает утверждение о присутствии данной тенденции в современном русском языке.

2) Тире вместо запятой

И. А. Долматова пишет, что «процесс своего рода универсализации тире в настоящее время настолько активен, что тире занимает позиции и запятой». Тенденция употребления тире вместо запятой наглядно представлена в примере ниже:

- «Было раннее летнее утро - часов шесть» («Комсомольская правда»). В данном примере содержится уточнение. Обычно в русском языке уточнение в предложении обосабливается запятой. Однако, согласно «Правилам русской орфографии и пунктуации» (Лопатин, 2007), для подчеркивания смысла уточняющие члены в тексте выделяются знаком тире (глава 80, раздел «Пунктуация»). И. А. Долматова пишет, что употребление тире в данной ситуации «обусловлено ярко выраженной разговорностью и выразительностью данных конструкций» (Долматова, онлайн).

3) Тире на месте нуля знаков

Касательно постановки тире на месте нуля знаков И. А. Долматова отмечает, что «ненормированное употребление тире стало настолько массовым и всеохватывающим, что оно теперь ставится там, где нужно, и там, где не нужно». Тенденция употребления тире на месте нуля знаков наглядно представлена в примере ниже:

- «Он сам - предприниматель и всегда внимательно присматриваетса $к$ газетным объявлениям» («Комсомольская правда»). Согласно «Правилам русской орфографии и пунктуации» тире в данном примере использоваться не должно (п. 1, глава 15, раздел «Пунктуация») (Лопатин, 2007). И. А. Долматова пишет о том, что подобные структуры с тире при подлежащем, выраженным личным местоимением, активны в газетном языке (Долматова, онлайн).

4) Tире при второстепенных членах предложения, подлежащих обособлению

Тенденция употребления тире при второстепенных членах предложения, подлежащих обособлению, наглядно представлена в примере ниже:

- «3а три недели путешествия на верблюдах мы пересекли огромные пространства - безлюдные и выжженные» («Литературная газета»). Согласно «Правилам русской орфографии и пунктуации» постановка тире перед определениями, стоящими в конце предложения допустима (глава 51, раздел «Пунктуация») (Лопатин, 2007). Однако автор статьи высказывает мнение, что «постановка определений в позицию конца фразы и выделение их при помощи тире воздействует на эмоциональную и образную среры личности реципиента, вызывая в сознании читающего соответствующие образы и эмоциональные реакции (Долматова, онлайн). 
Данные примеры показывают, что при допустимой факультативности знаков препинания авторы статей склоняются к выбору тире вместо использования классического знака препинания, рекомендованного правилами русской пунктуации. В изданиях средств массовой информации это происходит для придания большей выразительности и экспрессивности текстам и заголовкам, чтобы привлечь внимание читателя. Тире, как знак препинания, в настоящее время является знаком выразительным и эмоциональным.

Схожее мнение, касающееся тенденций постановки тире в печатных изданиях, высказывает и Е. В. Брусницына. Ею было проведено исследование, касающееся специфики пунктуационных норм в современном русском языке. В качестве анализируемых элементов выступали фрагменты газетных текстов, в которых присутствовала ошибочная или нерегламентированная пунктуация. Результаты ее исследования показали, что «постановка тире на месте нуля знаков или вместо запятой выполняет текстообразующую функцию в публицистике. Эта фуннция связана с желанием создателя текста (журналиста) подчеркнуть информативную значимость определенного сегмента высказывания или даже отдельного слова» (Брусницына, онлайн). Е. В. Брусницына считает, что «частотность и последовательность употребления тире в определенных синтаксических конструкциях (внутри простого предложения) позволяет сделать вывод о возрастающей значимости коммуникативного принципа русской пунктуации, по крайней мере в публицистических текстах» (Брусницына, онлайн).

Причиной развития тенденций является то, что при всей своей строгости пунктуация русского языка обладает гибкостью. Благодаря исторической изменяемости пунктуации и языка в целом функции знаков препинания, в том числе и тире, меняются и расширяются, что ведет к неизбежным отклонениям от норм, которые в первую очередь проявляются в изданиях печатной прессы, а позже охватывают и другие сферы литературных текстов.

\section{3 Методология исследования}

В контексте изучения современных тенденций факультативного употребления знаков препинания нами было проведено собственное исследование тенденций употребления тире в публицистических текстах наиболее популярных российских интернет-СМИ. Целью данного исследования являлось установить частотность употребления отдельных категорий пунктуационного знака тире, а также определить, какие тенденции использования тире, не отвечающие нормативной пунктуации, развиваются в современном русском языке.

Основными задачами исследования были:

1) определение частотности употребления определенных категорий тире, которые будут выделены в ходе анализа;

2) выяснение тенденций факультативного употребления тире, развивающихся в настоящее время.

Исследуемый образец составили предложения со знаком препинания тире, выбранные из статей наиболее популярных российских СМИ.

Источниками материала послужили следующие интернет-СМИ: газета «Аргументы и Факты», газета «Известия», газета «Правда», газета «Независимая газета», газета «Литературная газета», газета «Красная звезда», газета «Ведомости», интернет-издание «Газета.Ru», информационное агентство «РИА Новости» и интернет-ресурс «РБК». В Приложении 1 приводится основная информация об источниках материала, используемых в данном исследовании. 


\section{4 Ход и результаты исследования}

Выбор статей для исследования являлся нецеленаправленным: для анализа были использованы первые статьи, предложенные нам при открытии каждого интернет-ресурса. Это обеспечило случайный выбор статей с широким спектром тематики и гарантирует достоверность непредвзятого подхода к выбору образца для исследования. Исследуемый образец был составлен методом сплошной выборки всех предложений, содержащих пунктуационный знак тире в выбранных статьях интернет-СМИ. Каждый случай употребления тире был проанализирован в соответствии с теоретическими основами и правилами постановки тире согласно нормам и отклонениям от норм современной пунктуации русского языка.

В ходе нашего исследования мы проанализировали 115 предложений из 10 статей интернет-СМИ (7 газет, 1 интернет-издание, 1 информационное агентство и 1 интернет-портал). Результаты исследования основаны на 136 случаях употребления тире. Данные, полученные в результате анализа, представлены в таблице 1 ниже:

Таблица № 1

Категории употребления тире в предложении.

\begin{tabular}{|c|c|}
\hline \multicolumn{1}{|c|}{ Категория } & Количество употреблений \\
\hline $\begin{array}{c}\text { Tире в зависимости от структуры } \\
\text { предложения }\end{array}$ & 86 \\
\hline Tире при прямой речи & 35 \\
\hline Tире соединительное & 15 \\
\hline Tире интонационное & 0 \\
\hline
\end{tabular}

Результаты исследования, представленные в Таблице 1, показывают, что самое большое количество употреблений приходится на структурное тире и составляет 63,2\%. Далее следует тире при прямой речи, которое употребляется в $25,8 \%$ от всех рассматриваемых случаев. Соединительное тире встречается в $11 \%$ примеров. Интонационное тире в ходе исследования не обнаружено.

Процентное соотношение категорий употребления тире в предложении, полученное в ходе нашего исследования, представлено в Диаграмме № 1 ниже:

Диаграмма № 1: Категории употребления тире в предложении.

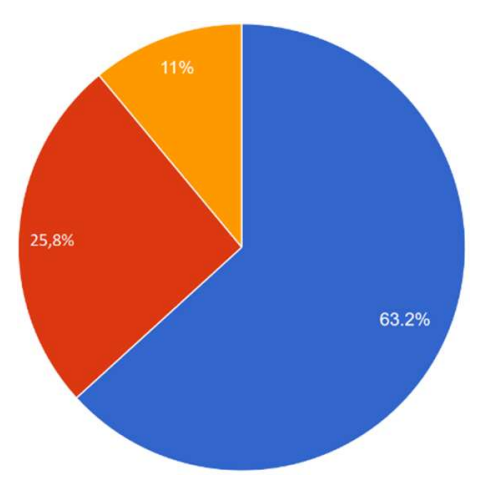

Тире в зависимости от структуры предложения

Тире при прямой речи

Тире соединительное 
Случаи употребления тире в каждой категории были проанализированы более подробно. В результате анализа была выявлена частотность употребления тире в отдельных подкатегориях, которая представлена в Таблице № 2.

Таблица № 2: Подкатегории употребления тире в публицистических текстах.

\begin{tabular}{|c|c|c|c|}
\hline Категория & $\begin{array}{c}\text { Количество } \\
\text { употреблений }\end{array}$ & Подкатегория & $\begin{array}{c}\text { Количество } \\
\text { употреблений }\end{array}$ \\
\hline \begin{tabular}{l}
\multicolumn{1}{c}{ Тире } \\
основной \\
структуре \\
предложения
\end{tabular} & 44 & $\begin{array}{l}\text { Tире между } \\
\text { подлежащим и сказуемым } \\
\text { Тире в предложениях } \\
\text { с уточняющими, с } \\
\text { пояснительными } \\
\text { присоединительными } \\
\text { членами } \\
\text { Тире в предложениях } \\
\text { с обособленными членами } \\
\text { Тире } \\
\text { внутритекстовых } \\
\text { примечаниях } \\
\text { Тире при словах, } \\
\text { грамматически не связанных } \\
\text { с ч } \\
\text { членами предложения } \\
\text { Тире в предложениях } \\
\text { с однородными членами }\end{array}$ & $\begin{array}{l}2 \\
1\end{array}$ \\
\hline \begin{tabular}{l}
\multicolumn{1}{c}{ Тире } \\
неполном \\
предложении
\end{tabular} & 22 & 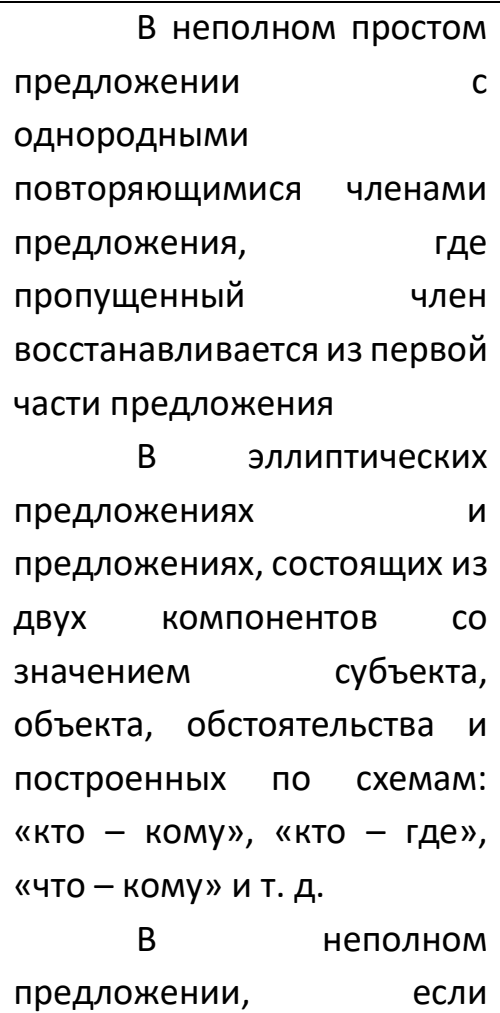 & . \\
\hline
\end{tabular}




\begin{tabular}{|c|c|c|c|}
\hline & & $\begin{array}{l}\text { отсутствующий } \\
\text { предложения } \\
\text { восстанавливается } \\
\text { предшествующих } \\
\text { предложений } \\
\quad \text { В неполном сложном } \\
\text { предложении } \\
\text { параллельной структурой }\end{array}$ & 1 \\
\hline \begin{tabular}{l}
\multicolumn{1}{c}{ Тире } \\
сложном \\
предложении
\end{tabular} & \begin{tabular}{l|l} 
B & \\
\end{tabular} & $\begin{array}{l}\text { Tире в бессоюзном } \\
\text { сложном предложении } \\
\text { Тире } \\
\text { сложноподчиненном } \\
\text { предложении } \\
\quad \text { Тире } \\
\text { сложносочиненном } \\
\text { предложении }\end{array}$ & 14 \\
\hline
\end{tabular}

Результаты исследования, представленные в Таблице 2, показывают, что самое большое количество примеров, в которых употребляется тире, относится к основной структуре предложения - 51,2\% (по убыванию: тире между подлежащим и сказуемым - 23,3\%; тире в предложениях с уточняющими, пояснительными и присоединительными членами - 12,8\%; тире в предложениях с обособленными членами - 7\%; тире при внутритекстовых примечаниях $-4,7 \%$; тире при словах, грамматически не связанных с членами предложения - 2,3\%; тире в предложениях с однородными членами -1,1\%).

Далее следуют неполные предложения - 25,6\% (по убыванию: в неполном простом предложении с однородными повторяющимися членами предложения, где пропущенный член восстанавливается из первой части предложения - 9,3\%; в эллиптических предложениях и предложениях, состоящих из двух компонентов со значением субъекта, объекта, обстоятельства и построенных по схемам: «кто - кому», «кто - где», «что - кому», - 8,1\%; в неполном предложении, если отсутствующий член предложения восстанавливается из предшествующих предложений, - 7\%; в неполном сложном предложении с параллельной структурой - 1,2\%).

Процент употребления тире в сложном предложении составил 23,2\% (тире в бессоюзном сложном предложении - 16,3\%; тире в сложноподчиненном предложении - 5,8\%; тире в сложносочиненном предложении - 1,1\%).

Процентное соотношение категорий употребления тире в зависимости от структуры предложения, полученное в ходе нашего исследования, представлено в Диаграмме № 2. 
Диаграмма № 2: Категории употребления тире в зависимости от структуры предложения.

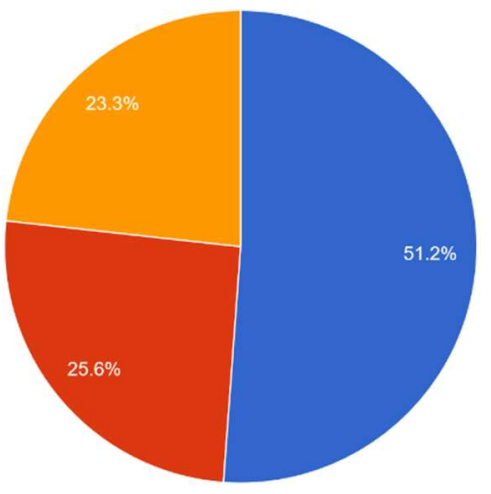

Тире в основной структуре

предложения

Тире в неполном

предложении

Тире в сложном

предложении

В исследовании также были проанализированы случаи замены нормативных пунктуационных знаков знаком тире и случаи ошибочной постановки тире. Помимо этого, выявлены 4 случая употребления тире, которое не регулируется пунктуационными нормами русского языка, и единичный случай ошибочного употребления дефиса вместо тире. Всего в исследуемом образце зафиксировано 137 случаев, из которых 136 уникальных случаев употребления тире и 1 случай ошибочного употребления дефиса вместо тире. Данные, полученные в результате анализа, представлены в Таблице № 3.

Таблица № 3: Нормативность употребления тире в предложении.

\begin{tabular}{|c|c|}
\hline Категория & Количество употреблений \\
\hline Тире употреблено согласно правилу & 108 \\
\hline Факультативное употребление тире & 16 \\
\hline Ошибочное употребление тире & 8 \\
\hline $\begin{array}{l}\text { Употребление тире, не регламентируемое } \\
\text { правилами }\end{array}$ & 4 \\
\hline Ошибочное употребление дефиса вместо тире & 1 \\
\hline
\end{tabular}

Результаты исследования, представленные в Таблице 3, показывают, что тире как нормативный пунктуационный знак употребляется в 78,9\%. В 11,7\% знак тире используется факультативно, т. е. заменяет нормативный знак, однако это делается в рамках, допустимых правилами (по убыванию: двоеточие - 6,6\%, запятая - 2,9\%, нуль знаков - 2,2\%). Ошибочно тире употребляется в 5,8\% случаев. Употребление тире, не регламентируемое правилами, зафиксировано в 2,9\% случаев. Процентная доля употребления дефиса вместо тире составляет 0,7\%. Процентное соотношение категорий, полученное в ходе нашего исследования, представлено в Диаграмме № 3. 
Диаграмма № 3: Нормативность употребления тире в предложении.

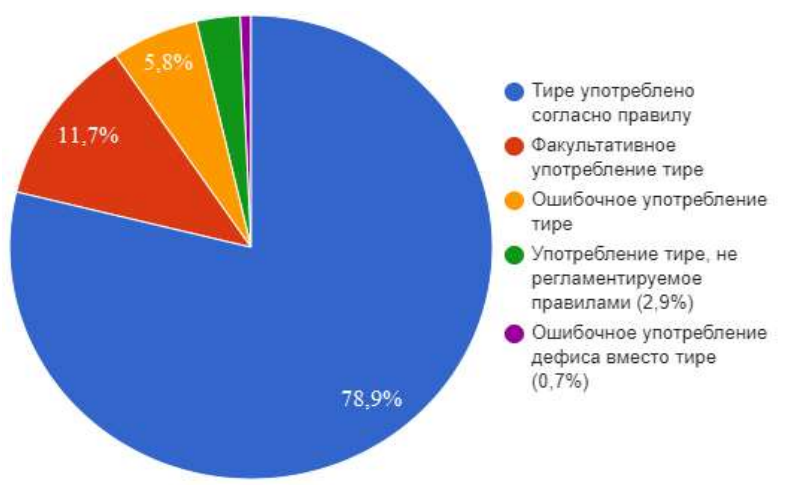

Результаты анализа показывают, что более 1/10 всех случаев использования тире приходится на его факультативное употребление. Чаще всего знаком тире заменяется двоеточие. Помимо этого, в ряде случаев заменяется запятая, а также тире употребляется на месте нуля знаков.

\section{5 Заключение}

Согласно результатам, полученным в ходе исследования, максимальное число случаев употребления тире пришлось на категорию Tuре в зависимости от структуры предложения, которое согласно классификации, представленной во второй части данной статьи, включало в себя тире в основной структуре предложения, тире в сложном предложении, а также тире в неполном предложении.

Тире в основной структуре предложения было употреблено 44 раза и включало в себя следующие категории:

- $\quad$ тире между подлежащим и сказуемым;

- $\quad$ тире в предложениях с уточняющими, пояснительными и присоединительными членами;

- $\quad$ тире в предложениях с обособленными членами;

- $\quad$ тире при внутритекстовых примечаниях;

- $\quad$ тире при словах, грамматически не связанных с членами предложения;

- $\quad$ тире в предложениях с однородными членами.

Тире между подлежащим и сказуемым было отмечено в 20 случаях и выполняло одну из своих основных функций - употреблялось в качестве замены отсутствующей связки. Помимо этого, тире употреблялось на месте нуля знаков для обозначения логического подчеркивания. Постановка тире при уточняющих, поясняющих и присоединительных членах предложения была выявлена в ходе исследования в 11 анализируемых примерах и обусловлена тем, что в статьях подчеркивался смысл тех или иных слов для придания им большего значения, для акцентирования внимания читателя. Тире в таких ситуациях выступал как заметный, привлекающий внимание к себе и к словам, которые он выделял, знак, что отвечает концепции публицистических текстов. Постановка тире при обособленных членах была зафиксирована в ходе исследования в 6 примерах, половина из которых приходилась на случаи, где данный пунктуационный знак использовался для смыслового выделения. При внутритекстовых примечаниях тире было употреблено 4 раза. Такие примечания характерны для публицистических статей, так как в них приводятся дополнительные объяснения, замечания и информация, дающиеся автором к содержанию. Тире при словах, грамматически не связанных 
с членами предложения, в двух рассмотренных случаях было употреблено ошибочно. Тире в предложении с однородными членами было употреблено после обобщающего слова вместо нормативного двоеточия, однако в современном русском языке постановка тире допускается при любой позиции обобщающего слова в предложении. Данный факт являлся одним из подтверждений нашего предположения касательно того, что тире в настоящее время перенимает функции и позиции других знаков препинания.

Тире в неполных предложениях было употреблено 22 раза, что, во-первых, было обусловлено тем, что в роли неполных предложений выступали как простые, так и сложные предложения. Во-вторых, тире в данных предложениях заменяло любой возможный пропущенный член. Немаловажным фактором также являлось то, что неполные предложения, построенные по схеме: «кто - кому», «кто - куда», «что - куда» и т. д. характерны для газетных статей и их заголовков. На это указывает как Д. Э. Розенталь в «Справочнике по русскому языку: орфография и пунктуация», так и информация из «Правил русской орфографии и пунктуации» под редакцией В. В. Лопатина. Несмотря на то, что предложения, построенные по данной схеме, являются краткими, они понятны, информативны и привлекают внимание читателя, что отвечает целям авторов публицистических статей и концепции СМИ в целом.

Тире в сложном предложении было употреблено 20 раз и включало в себя следующие подкатегории:

- $\quad$ тире в сложносочиненном предложении;

- $\quad$ тире в сложноподчиненном предложении;

- $\quad$ тире в бессоюзном сложном предложении.

Тире в бессоюзных сложных предложениях более чем в половине проанализированных примеров, а именно - в 8 из 14 предложений, было употреблено вместо двоеточия, что являлось подтверждением смешения функций данных пунктуационных знаков и свидетельствовало о том, что в настоящее время в русском языке тире активно перенимает функции двоеточия и употребляется вместо него в бессоюзных сложных предложениях.

Тире в сложноподчиненном предложении было употреблено в 5 проанализированных примерах: из них 3 случая были определены нами как ошибочные, следовательно в рамках данной бакалаврской работы не представлялось возможным установить причины постановки тире и функции, которые должен был выполнять такой пунктуационный знак в тексте; единичный случай был зафиксирован при усилении вопросительного характера предложения, что добавляет экспрессивности данному предложению $и$ соответствует целям публицистического текста; единичный случай был зафиксирован при «переломе» конструкции, перед словом это.

Единичное употребление тире в сложносочиненном предложении было нами классифицировано как стилистический прием, направленный на определенное эмоциональное воздействие на читателя со стороны автора, что соответствует установке публицистических текстов.

Далее, согласно полученным результатам, более четверти всех случаев употребления тире пришлось на категорию «тире при прямой речи». Это обусловлено тем, что в статьях часто приводятся выдержки из различных интервью, которые оформляются в виде прямой речи.

Тире соединительное в ходе нашего исследования было найдено в 15 случаях от общего числа употреблений. При помощи данного тире в статьях оформлялись пространственные пределы, а именно - названия трасс, количественные пределы при описании процентных долей, 
временные пределы при упоминании каких-либо временных промежутков, также соединительное тире использовалось в названиях мероприятий и объектов.

Помимо категорий употребления тире в предложениях с точки зрения его функции в нашем исследовании также была проанализирована нормативность употребления данного пунктуационного знака. В ходе исследования факультативное употребление тире было зафиксировано в 11,7\% проанализированных примеров, а именно-были зафиксированы случаи факультативной замены знаком тире таких знаков, как двоеточие, запятая, а также нуль знаков.

На долю ошибок в употреблении тире и единичного случая употребления дефиса вместо тире, зафиксированных в ходе исследования, пришлось 6,5\% от общего количества анализируемых примеров. Установить точную природу возникновения данных ошибок в рамках исследования не представлялось возможным, т. к. наше научное исследование опиралось на правила, регламентирующие нормативное и факультативное употребление пунктуационных знаков, и не затрагивало проблематику ненормативной пунктуации, в том числе и авторской пунктуации. С другой стороны, в ходе исследования встречались и другие различные пунктуационные ошибки, как, например, пропуск запятых в некоторых предложениях, поэтому мы придерживаемся мнения, что статьи, опубликованные в средствах массовой информации, не могут быть стандартом нормативной пунктуации, на который следует ориентироваться.

В ходе нашего исследования также были зафиксированы 4 случая употребления тире, которые не регламентируются пунктуационными нормами русского языка, однако фиксируются редакционными нормами. С точки зрения нормативности, они попадают под категорию ненормативной пунктуации, но, с точки зрения иных сводов правил, употребление тире в данных случаях было оправдано, поэтому данные примеры не были отнесены к категории ошибочного употребления тире.

Полученные результаты дают ответ на основной вопрос нашего исследования: в современном русском языке существуют тенденции в употреблении тире, а именно - тенденция факультативного употребления тире вместо нормативных знаков, регламентируемых пунктуационными нормами. Однако важным аспектом подобного употребления тире является то, что оно не выходит за рамки существующих правил, но при этом характерно для определенных типов текстов - публицистических.

\section{Использованная литература / References:}

\section{Печатные источники:}

ЛОПАТИН, В. В. Правила русской орфографии и пунктуации: Полный академический справочник. Москва: Эксмо, 2007. ISBN 978-5-699-18553-5.

\section{Онлайн-источники:}

БРУСНИЦЫНА, Е. В. (онлайн). Пунктуационная норма современного русского языка как проблема деятельности корректора: на материале газетных текстов. Омск, 2010. Режим доступа: https://www.dissercat.com/content/punktuatsionnaya-norma-sovremennogorusskogoyazyka-kak-problema-deyatelnosti-korrektora [дата обращения 11. 11. 2019].

ВАЛГИНА, Н. С. [1]. (онлайн). Актуальные проблемы современной русской пунктуации: учеб. пособие. Москва: Высшая школа, 2004. ISBN 5-06-004937-X. [online]. Режим доступа: http://yanko.lib.ru/books/language/ru/valgina.aktualnuye_ptobl_rus_punkt.2004.259_(sl).htm [дата обращения 11. 11. 2019]. 
ВАЛГИНА, Н. С. [2] (онлайн). Русская пунктуация: принципы и назначение. Пособие для учителей: Функции знаков препинания. Знаки отделяющие и знаки выделяющие [online]. Режим доступа: http://genling.ru/books/item/f00/s00/z0000037/st009.shtml [дата обращения: 13. 10. 2019].

ВАЛГИНА, Н. С. [3]. (онлайн). Синтаксис современного русского языка: Понятие авторской пунктуации. Режим доступа: http://www.hi-edu.ru/e-books/xbook089/01/part-060.htm [дата обращения: 13. 10. 2019].

ВАЛГИНА, Н. С., Д. Э. РОЗЕНТАЛЬ И М. И. ФОМИНА. (онлаЙН). СовременнЫй русский язык: Учебник: 366.Основные функции знаков препинания 6-е изд., перераб. и доп. Москва: Логос. ISBN 5-94010-008-2. [online]. Режим доступа: http://www.hi-edu.ru/e-books/xbook107/01/part206.htm\#i134322002 [дата обращения: 05. 11. 2019].

ВАЛГИНА, Н. С. и В. Н. СВЕТЛЫШЕВА. (онлайн). Орфография и пунктуация. Справочник: 2.16. Нерегламентированная пунктуация. Авторская пунктуация 2.16.1. Причины появления нерегламентированной пунктуации [online]. Режим доступа: http://www.hi-edu.ru/ebooks/xbook142/01/part-035.htm\#i17016 [дата обращения: 13. 10. 2019].

ДИВАКОВА, М. В. (онлайн). Принципы пунктуации и нормы синтаксических построений русского литературного языка первой трети XX века: На материале произведений поэтов и писателей XX века. Москва, 2006. Режим доступа: https://www.dissercat.com/content/printsipypunktuatsii-i-normy-sintaksicheskikh-postroenii-russkogo-literaturnogo-yazyka-perv/read [дата обращения: 13. 10. 2019].

ДОЛМАТОВА, И. А. (онлайн). Тенденции в употреблении тире в конце XX - начале XXI века. Вестник ПСТГУ. Режим доступа: http://pstgu.ru/download/1172689007.dolmatova.pdf [дата обращения 11. 11. 2019].

ЛАРИОНОВА, А. Ю. (онлайн). Динамические языковые прочессы: в помощь будущему редактору [online]. Екатеринбург: Издательство Уральского университета, 2018. ISBN 978-57996-2481-1. Режим доступа: http://elar.urfu.ru/bitstream/10995/62824/1/978-5-7996-24811_2018.pdf [дата обращения 11. 11. 2019].

РОЗЕНТАЛЬ, Д. Э. (онлайн). Справочник по русскому языку: орфография и пунктуация: раздел 19. Факультативные знаки препинания. Режим доступа: http://oldrozental.ru/punctuatio.php?sid=182\#pp182 [дата обращения 11. 11. 2019].

\section{Профиль автора:}

Александра Чебан, бакалавр, студентка магистратуры

Научные интересы: синтаксис русского языка, стилистика русского языка, грамматика русского языка e-mail: sashacheban96@mail.ru

Место учебы: Кафедра русского языка и литературы, Педагогический факультет, Университет им.

Масарика, Поржичи 7/9, Брно, 60300

\section{Author's profile:}

Aleksandra Cheban, Bc., master's degree student

Research interests: syntax of the Russian language, stylistics of the Russian language, grammar of the Russian language

e-mail: sashacheban96@mail.ru

Place of work/university: Department of Russian language and literature, Faculty of Education, Masaryk University, Poříčí 7/9, Brno, 60300 


\section{Профиль автора:}

Янина Крейчи, магистр, преподаватель русского языка

Научные интересы: синтаксис русского языка, дидактика иностранных языков, речевая вежливость, социолингвистическая компетенция

e-mail: janina.krejci@ped.muni.cz

Место работы: Кафедра русского языка и литературы, Педагогический факультет, Университет им. Масарика, Поржичи 7/9, Брно, 60300

\section{Author's profile:}

Janina Krejčí, Mgr., teacher of Russian language

Research interests: syntax of the Russian language, didactics of foreign languages, speech politeness, sociolinguistic competence

e-mail: janina.krejci@ped.muni.cz

Place of work: Department of Russian language and literature, Faculty of Education, Masaryk University, Poříči $7 / 9$, Brno, 60300

Приложение

\section{Интернет-СМИ - источники материала для исследования}

1) «Аргументы и Факты» - российская еженедельная общественно-политическая газета. «Аргументы и факты» стали выходить в 1978 году как методическое пособие в помощь лекторам и пропагандистам, издаваемый Всесоюзным обществом «Знание». В 1980 году «АиФ» стали выходить в виде еженедельной газеты. В 1990 году тираж «Аргументов и Фактов» был зафиксирован Книгой рекордов Гиннеса, как самый масштабный тираж в мире. Он составил 33,5 миллиона экземпляров. Газета распространяется по подписке и в розницу в 60 странах мира, в том числе в США, Канаде, Австралии. "АиФ" обладает и самой обширной сетью региональных редакций - 66 в России, 16 - за рубежом. По данным источника Liveinternet сайт «АиФ» ежемесячно посещает 28,6 миллионов пользователей по всему миру, и он занимает 12 строчку в рейтинге посещаемости.

2) Газета «Известия» ведет свою историю с 1917 года и по праву считается одним из старейших изданий России. Выходя пять раз в неделю с понедельника по пятницу, газета привлекает внимание читательской аудитории более чем в 450 тыс. человек. Тематика газеты - освещение событий в России и за рубежом, аналитика и комментарии, обзор вопросов бизнеса и экономики, событий культурной и спортивной жизни. По данным источника Liveinternet сайт «Известий» ежемесячно посещает более 44,5 миллионов пользователей по всему миру, и он занимает 5 строчку в рейтинге посещаемости. Газета «Известия» занимает 1 место в рейтинге «Топ-10 самых цитируемых газет - сентябрь 2019».

3) «Правда» - газета, до 1991 года основное ежедневное печатное средство массовой информации КПСС и наиболее влиятельное печатное издание, фактически - главная газета в СССР. После запрета КПСС - орган КПРФ, Выходит трижды в неделю. Газета и сегодня несёт в массы социалистические идеалы. «Правда» служит главной трибуной КПРФ, публикует основные документы партии, разъясняет её позицию по актуальным вопросам современности.

4) «Независимая газета» - одно из крупнейших периодических изданий современной России, посвященное актуальным проблемам общественной, политической и культурной жизни в России и за ее пределами. Выходит с 21 декабря 1990 года. В газете ежедневно публикуются материалы ведущих 
журналистов, политологов, историков, искусствоведов, критиков. Выходит также восемь тематических приложений к газете.

5) «Литературная газета» была основана поэтом Антоном Дельвигом при участии Александра Пушкина и Петра Вяземского. Газета выходила один раз в пять дней, ее первым редактором был Антон Дельвиг. 13 января (1 января по старому стилю) 1830 года в свет вышел первый номер. Газета выходила до 30 июня 1831 года. В 1840 году выпуск газеты был возобновлен и продолжался до 1849 года. Издание «Литературной газеты» было возобновлено только в XX веке. 22 апреля 1929 года, при участии писателя Ивана Катаева и при поддержке Максима Горького вышел первый номер новой «Литературной газеты» и с этой даты ведется отсчет регулярного выпуска газеты. В настоящее время «ЛГ» - общественнополитический еженедельник для широкого круга интеллигенции. Фактически это четыре газеты (тетради) под одной обложкой, посвященные политике и экономике, обществу, литературе и искусству, человеку.

6) «Красная звезда» - главный печатный орган Министерства обороны Российской Федерации (до 1991 г. - Министерства обороны СССР) по сей день продолжает обеспечивать единое информационное поле не только для Вооружённых Сил, но и для Пограничных, Внутренних, Железнодорожных войск, войсковых формирований других государственных силовых ведомств. Газета публикует материалы о деятельности российских воинов в районах локальных военных конфликтов, о конверсии на оборонных предприятиях, о проблемах сохранения потенциала отечественного военнопромышленного комплекса.

7) «Ведомости» - старейшая газета России, выпускаемая с 1703 года. Современная ежедневная деловая газета выходит с 1999 года. В газете представлена информация об экономических, финансовых, корпоративных и политических событиях, анализ и прогнозы развития ситуации. Сайт издания запущен в 1999 году одновременно с печатной версией газеты. На сайте содержится архив материалов, публиковавшихся в газете начиная с первого выпуска в 1999 года. Газета «Ведомости» занимает 4 место в рейтинге «Топ-10 самых цитируемых газет - сентябрь 2019».

8) «Газета.Ru» - общественно-политическое интернет-издание, основанное в 1999 г. Круглосуточно освещает российские и мировые новости. По данным источника Liveinternet сайт «Газета.Ru» ежемесячно посещает более 33,3 миллионов пользователей по всему миру, и он занимает 8 строчку в рейтинге посещаемости. Данное интернет-издание занимает 4 строчку в рейтинге «Топ-30 самых цитируемых Интернет-ресурсов - сентябрь 2019».

9) «РИА Новости» - это одно из крупнейших информационных агентств в мире. Главная задача «РИА Новости» состоит в оперативном и многоплановом предоставлении российской и зарубежной аудиториям достоверных и объективных новостей о событиях в России и во всем мире. Данный ресурс является главным поставщиком информации для Администрации Президента, Правительства России, Совета Федерации и Государственной Думы, ведущих министерств и ведомств, администраций субъектов Федерации, СМИ, представителей деловых кругов и общественных организаций. Данное информационное агентство занимает 1 строчку в рейтинге «Топ-3 самых цитируемых информационных агентств - сентябрь 2019». По данным источника Liveinternet сайт «РИА Новости» ежемесячно посещает более 53,3 миллионов пользователей по всему миру, и он занимает 2 строчку в рейтинге посещаемости.

10) «РБК» - российский медиахолдинг, объединяющий телеканал РБК-ТВ, интернет-СМИ и печатные издания. Информационное агентство РБК было создано в Москве 17 июня 1993 г. В 1995 г. РБК первым из российских информационных агентств создал собственный Интернет-сервер, а также организовал региональную корреспондентскую сеть. В 2003 г. начал работу телеканал РБК-ТВ. С 2006 г. издается ежемесячный деловой журнал РБК, а также печатная версия электронной ежедневной деловой 
газеты «РБК daily». По данным источника Liveinternet сайт «РБК» ежемесячно посещает более 42,4 миллионов пользователей по всему миру, и он занимает 7 строчку в рейтинге посещаемости. Данный интернет-ресурс занимает 1 строчку в рейтинге «Топ-30 самых цитируемых Интернет-ресурсов - сентябрь 2019». 